\title{
Colour characteristics of winter wheat grits of different grain size
}

\author{
Zs. H. Horváth \\ e-mail: horvatzs@mk.u-szeged.hu \\ A. Véha \\ e-mail: veha@mk.u-szeged.hu \\ University of Szeged, Faculty of Engineering, \\ 6725 Moszkvai Sq. 9, Szeged, Hungary
}

\begin{abstract}
Nowadays, wheat has spread all over the world due to its extensive usability. The colour of wheat grits is very important for the milling and baking industry because it determines the colour of the products made from it. The instrumental colour measuring is used, first of all, for durum wheat. We investigated the relationship between colour characteristics and grain size in the case of different hard aestivum wheats. We determined the colour using the CIE (Commission Internationale de l'Eclairage) $1976 \mathrm{~L}^{*}, \mathrm{a}^{*}, \mathrm{~b}^{*}$ colour system measured by MINOLTA CR-300 tristimulus colorimeter. After screening the colour of the wheat fractions of different grain size, grits was measured wet and dry. We determined the $\mathrm{L}^{*}, \mathrm{a}^{*}, \mathrm{~b}^{*}$ colour co-ordinates and the whiteness index, too. To evaluate the values we had obtained, we used analysis of variance and regression analysis. We pointed out that the colour of wheat grits of different grain size is dependent on the hardness index of wheat. The lightness co-ordinate $\left(\mathrm{L}^{*}\right)$ of grits of the harder wheat is smaller, while $\mathrm{a}^{*}$ and $\mathrm{b}^{*}$ co-ordinates are higher. We also found that while grain size rises, the $\mathrm{L}^{*}$ co-ordinate decreases and $\mathrm{a}^{*}, \mathrm{~b}^{*}$ values increase in the case of every type of wheat. The colour of grits is determined by the colour of fractions of 250-400 $\mu \mathrm{m}$ in size, independently from the average grain size. The whiteness index and the $\mathrm{L}^{*}$ colour co-ordinate have a linear relation $\left(\mathrm{R}^{2}=0.9151\right)$; so, the determination of whiteness index is not necessary. The $\mathrm{L}^{*}$ value right characterizes the whiteness of grits.
\end{abstract}

Keywords and phrases: colour measurement, wheat grits, colour of wheat. 


\section{Introduction}

Wheat grindings are one of the most important and most frequently used raw materials. As for every alimentary product, colour is an important parameter for wheat grindings as well, giving them a primary image, especially for the durum wheat pasta since they do not contain eggs. This explains the fact why instrumental colour measurements are applied on durum semolinas in industrial practices as well. In literature, various research results report on the colour measurements of wheat grindings. Already in 1993, Oliver et al. (1993) showed, during the qualification, that ash content influences the colour of flours. Halászné et al. (1995) proposed a qualification system based on the colour measurements of durum semolina. D'egido \& Pagani (1997) compared the colour characteristics of pasta made of durum flours obtained by different grinding procedures.

During the product manufacturing, the colour characteristics were mainly used to determine the appropriate roastedness (Hotti et al., 2000). Humphries et al. (2004) found a correlation between CIE b* and the lutein concentration of wheat. Konopka et al. (2004) established a relation between the colour characteristics of the flours and their lipid and colorant content. Gökmen \& Senyuva (2006) investigated the effect of heating on the colour parameters of wheat flour. László et al. (2008) examined the effects of ozone, UV and combined ozone/UV treatment on the colour of wheat flour. Lamsal \& Faubion (2009) studied the effect of an enzyme preparation on wheat flour and dough colour and suggested that enzyme preparation did not improve the lightness $\left(\mathrm{L}^{*}\right)$ and yellowness $\left(\mathrm{b}^{*}\right)$ of the flour system, but benzoyl-peroxide sharply reduced $b^{*}$.

We investigated how the colour characteristics depend on the grain size and hardness index of wheat. The relationship between the lightness co-ordinate and whiteness index was analysed too.

\section{Materials and methods}

\section{Materials}

In the course of our investigation, we used three different hard wheats. We can see their genus and hardness indexes in Table 1. At first, the samples were milled in drawn and air-dry condition, and then their colour characteristics were measured. 
Table 1: Wheat genus and their hardness index

\begin{tabular}{llc}
\cline { 2 - 3 } & \multicolumn{1}{c}{ Wheat genus } & Hardness index \\
\cline { 2 - 3 } & GK-Jubilejnaja-50 (J-50) & 80.44 \\
GK-Öthalom (Öthalom) & 71.66 \\
GK-Mérö (Mérö) & 20.78 \\
\hline
\end{tabular}

The $250 \mathrm{~g}$ of grits made of different wheat types was screened for 10 minutes to separate particles of different grain size. Table 2 shows the grading limits of fractions. Then we measured the mass and colour co-ordinates of the parts.

Table 2: Grading limits of classes

\begin{tabular}{c}
\hline Grading limits of classes \\
\hline $0 \mu \mathrm{m}-100 \mu \mathrm{m}$ \\
$100 \mu \mathrm{m}-250 \mu \mathrm{m}$ \\
$250 \mu \mathrm{m}-400 \mu \mathrm{m}$ \\
$400 \mu \mathrm{m}-600 \mu \mathrm{m}$ \\
$600 \mu \mathrm{m}-800 \mu \mathrm{m}$ \\
$800 \mu \mathrm{m}-1,000 \mu \mathrm{m}$ \\
$1,000 \mu \mathrm{m}-1,250 \mu \mathrm{m}$ \\
\hline
\end{tabular}

We determined the colour using the CIE $1976 \mathrm{~L}^{*}, \mathrm{a}^{*}, \mathrm{~b}^{*}$ colour system measured by MINOLTA CR-300 tristimulus colorimeter. In the CIE 1976 colour space, the colour points are characterized by three colour co-ordinates. $\mathrm{L}^{*}$ is the lightness co-ordinate, ranging from no reflection for black $\left(\mathrm{L}^{*}=0\right)$ to perfect diffuse reflection for white $\left(\mathrm{L}^{*}=100\right)$. $\mathrm{a}^{*}$ is 'the redness' co-ordinate, ranging from negative values for green to positive values for red. $b^{*}$ is 'the yellowness' co-ordinate, ranging from negative values for blue and positive values for yellow. The total colour change is given by the colour difference $\left(\Delta \mathrm{E}_{\mathrm{ab}}^{*}\right)$ in terms of the spatial distance between two colour points interpreted in the colour space (Park, 1993).

$$
\Delta \mathrm{E}_{\mathrm{ab}}^{*}=\sqrt{\left(\mathrm{L}_{1}^{*}-\mathrm{L}_{2}^{*}\right)^{2}+\left(\mathrm{a}_{1}^{*}-\mathrm{a}_{2}^{*}\right)^{2}+\left(\mathrm{b}_{1}^{*}-\mathrm{b}_{2}^{*}\right)^{2}}
$$

If $\Delta \mathrm{E}_{\mathrm{ab}}^{*}<3$, then the colour difference between two grists cannot be visually distinguished. The $\mathrm{L}^{*}$ (lightness), $\mathrm{a}^{*}$ (redness) and $\mathrm{b}^{*}$ (yellowness) parameters as well as whiteness index (WI) were measured. The measurements were made on 5 parallel samples and the colour co-ordinates were measured dry and wet. We estimated the measured values using analysis of variance and regression analysis (Rice, 1995). 


\section{Results and discussion}

Effect of the hardness index of wheat on colour co-ordinates

As the result of the analysis of variance, we made a comparison for the colour co-ordinates of different hard wheats as you can see in Figure 1 a) and Figure $1 \mathrm{~b})$. We could say that the $\mathrm{L}^{*}$ and $\mathrm{a}^{*}$ co-ordinates of hard wheats J-50 and Öthalom do not differ significantly, but they significantly differ from Mérö, having a hardness index of 20.78 .
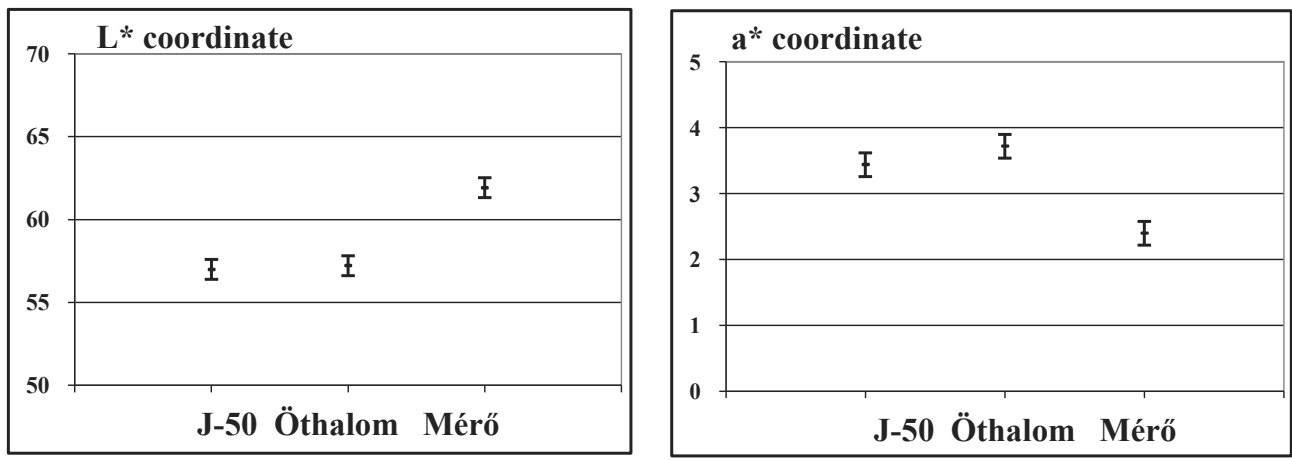

a)

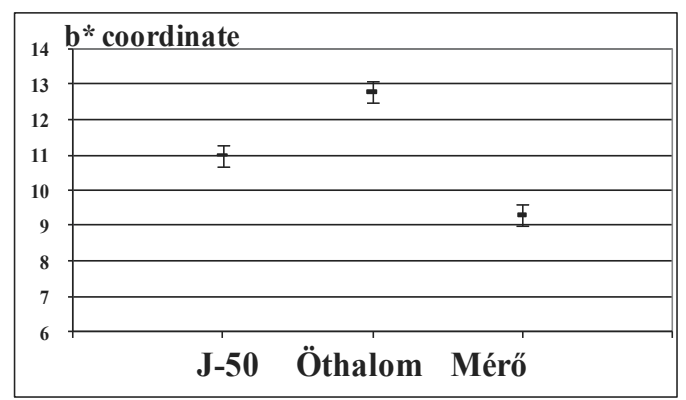

b)

Figure 1: Effect of the hardness of wheat on colour co-ordinates - results of the analysis of variance (averages $\pm^{1} /{ }_{2} \mathrm{SD}_{95 \%}$ )

The $\mathrm{b}^{*}$ yellowness co-ordinates of hard wheat are higher. Therefore, we can say that the colour of wheat with high hardness index was darker, redder and yellower. 


\section{Relationship between whiteness index and lightness co-ordinate}

The relationship of whiteness index and $\mathrm{L}^{*}$ lightness co-ordinate was examined. In Figure 2, we plotted the whiteness indexes as a function of lightness co-ordinates measured on wet samples. The equation of regression line and the determination coefficient are represented in the figure.

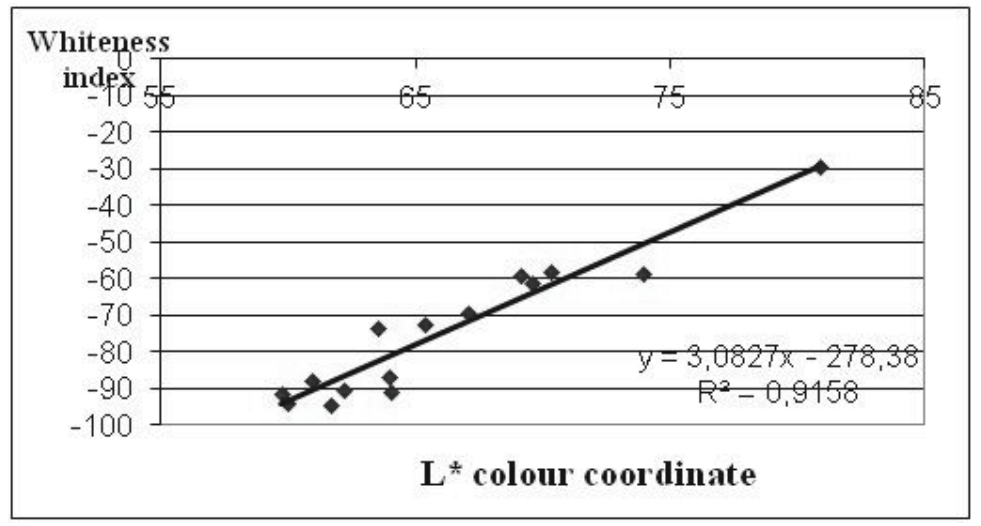

Figure 2: The relationship between whiteness index and lightness co-ordinate was measured wet.

We can see that they have a significant linear relation $(\mathrm{r}=0.9151)$, so the determination of whiteness index is not necessary. The $\mathrm{L}^{*}$ value characterizes the whiteness of grits.

\section{Effect of grain size on colour co-ordinates}

The results of the analysis of variance were calculated on colour parameters of fractions of different grain size, which in the case of J-50, Öthalom and Mérö wheats were similar. The $\mathrm{L}^{*}$ lightness co-ordinate, $\mathrm{a}^{*}$ redness co-ordinate and $b^{*}$ yellowness co-ordinate were significantly influenced by grain size. We only present the results obtained in the case of J-50 wheat.

In Figure 3, we marked the average values with significant differences that appertain to the $95 \%$ probability level (SD95\%). It seems that while grain size increases, the $\mathrm{L}^{*}$ co-ordinate decreases. Consequently, the grains smaller than $100 \mu \mathrm{m}$ are the lightest and whitest ones, while the bigger grains are the darkest ones. $a^{*}$ co-ordinate and $b^{*}$ co-ordinate increase, while grain size increases; thus, the bigger grains are redder and yellower. 

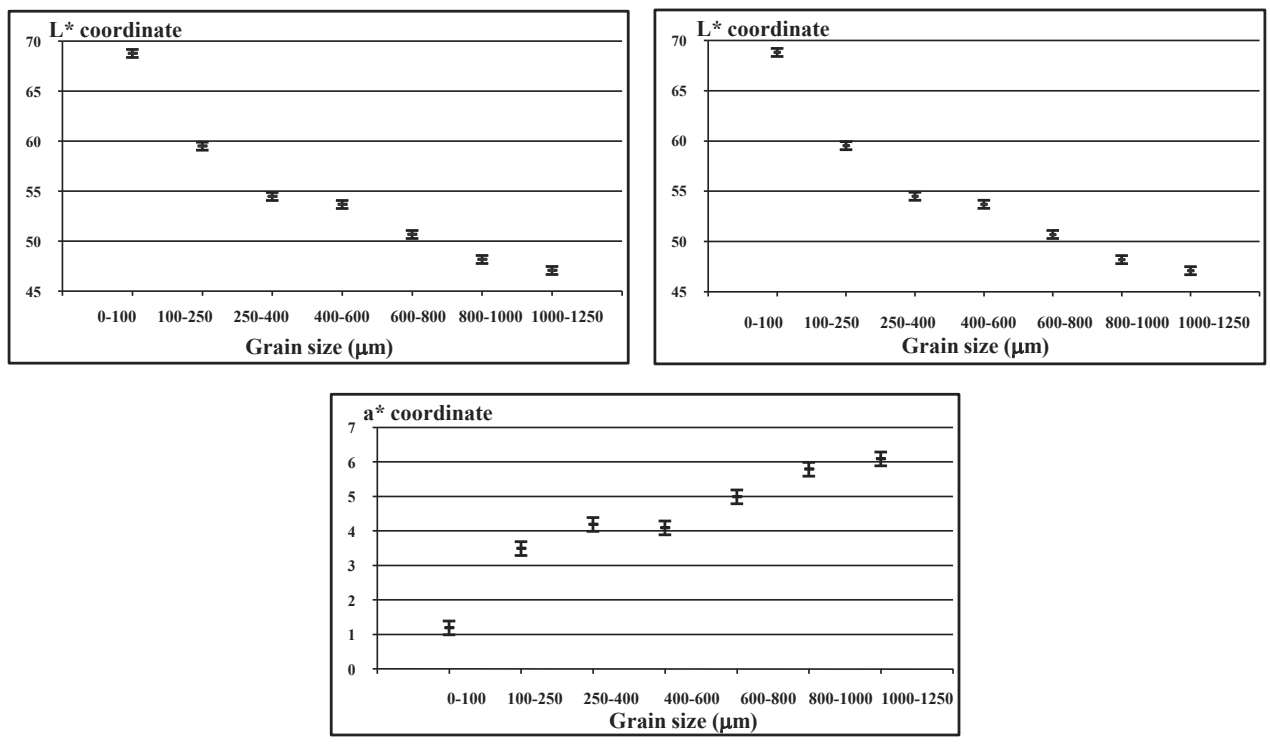

Figure 3: Effect of grain size on colour co-ordinates. Results of the analysis of variance (averages $\pm^{1} / 2 \mathrm{SD}_{95 \%}$ )

We analysed what grain sizes determined the colour of grits. Therefore, we calculated the colour difference values between grits and their fractions of different grain size. We can show the results in Table 3. It was found that the smallest $\Delta \mathrm{E}_{\mathrm{ab}}^{*}$ values were obtained in the case of the $250-400-\mu \mathrm{m}$ fractions at all times.

Table 3: Colour difference between wheaten grits and their fractions of different grain size

\begin{tabular}{crrr}
\hline Grain size $(\mu \mathrm{m})$ & Öthalom & \multicolumn{1}{c}{ J-50 } & \multicolumn{1}{c}{ Mérő } \\
\hline $0-100 \mu \mathrm{m}$ & 12.427 & 12.147 & 11.050 \\
$100-250 \mu \mathrm{m}$ & 3.055 & 2.602 & 5.292 \\
$250-400 \mu \mathrm{m}$ & 1.542 & 2.849 & 1.934 \\
$400-600 \mu \mathrm{m}$ & 2.777 & 3.698 & 3.587 \\
$600-800 \mu \mathrm{m}$ & 5.466 & 6.722 & 10.832 \\
$800-1,000 \mu \mathrm{m}$ & 8.134 & 9.315 & 10.081 \\
$1,000-1,250 \mu \mathrm{m}$ & 8.699 & 10.327 & 14.244 \\
\hline
\end{tabular}

So, they determine the colour of grits despite that these grain size fractions shown in Table 4 - are only $11.80-16.67 \%$ of the whole grits. 
Table 4: Grain size distribution of samples (\%)

\begin{tabular}{crrr}
\hline Grain size & JK-50 & Öthalom & Mérö \\
\hline $0 \mu \mathrm{m}-100 \mu \mathrm{m}$ & 3.75 & 3.15 & 4.85 \\
$100 \mu \mathrm{m}-250 \mu \mathrm{m}$ & 11.38 & 12.20 & 18.90 \\
$250 \mu \mathrm{m}-400 \mu \mathrm{m}$ & 11.80 & 11.80 & 16.47 \\
$400 \mu \mathrm{m}-600 \mu \mathrm{m}$ & 32.60 & 31.99 & 31.01 \\
$600 \mu \mathrm{m}-800 \mu \mathrm{m}$ & 32.99 & 34.15 & 20.91 \\
$800 \mu \mathrm{m}-1,000 \mu \mathrm{m}$ & 6.42 & 6.02 & 5.52 \\
$1,000 \mu \mathrm{m}-1,250 \mu \mathrm{m}$ & 1.06 & 0.69 & 2.34 \\
\hline
\end{tabular}

In conclusion, we can say that the colour parameters of wheat grits are significantly dependent on grain size; upon increasing, the grits become darker and redder. The colour of wheat grits is determined by the colour of grains between 250 and $400 \mu \mathrm{m}$. The colour of wheaten grits of different grain size is dependent on the hardness index of wheat. The lightness co-ordinate $\left(\mathrm{L}^{*}\right)$ of the grits of the harder wheat is smaller, while $\mathrm{a}^{*}$ and $\mathrm{b}^{*}$ co-ordinates are higher. The whiteness index and the $\mathrm{L}^{*}$ colour co-ordinate have a linear relation $(\mathrm{r}=0.9151)$; so, the determination of whiteness index is not necessary.

\section{References}

[1] J. Oliver, A. Blakeney, H. Allen, The colour of flour streams related to ash and pigment contents. Journal of Cereal Science, 17. 2. (1993) 169-182.

[2] J. Park, Instrumental colour formulation: a practical guide. North Carolina State University. (1993).

[3] M. Halászné-Fekete, P. Záhonyiné-Racs, Á. Keleti, Colour measurement of durum grits for aim of qualification in paste industry. Book of the $X X V^{\text {th }}$ Colouristic Symposium. (1995) 41-48.

[4] J. A. Rice, Mathematical statistics and data analysis. Duxbury Press. (1995)

[5] M. D'Egidio, M. Pagani, Effect of the different stages of durum wheat chain on pasta colour. Italian Food \& Beverage Technology, 10. (1997) $17-20$. 
[6] A. Hotti, S. Sidhu, J. Al-Sager, Utillty of CIE tristimulus system in measuring the objective crumb colour of high-fibre toast bread formulation. Journal of Food Quality, 23. 1. (2000) 103-116.

[7] I. Konopka, W. Kozirok, D. Rotkiewicz, Lipids and carotenoids of wheat grain and flour and attempt of correlating them with digital image analysis of kernel surface and cross-sections. Food Research International, 37. 5. (2004) 429-438.

[8] J. M. Humphries. R. D. Graham, \& D. J. Mares, Application of reflectance colour measurement to the estimation of carotene and lutein content in wheat and triticale. Journal of Cereal Science, 40. (2004) 151-159.

[9] V. Gökmen, H. Z. Şenyuva, Study of colour and acrylamide formation in coffee, wheat flour and potato chips during heating. Food Chemistry, 99. (2006) 238-243.

[10] Zs. László, Zs. Hovorka-Horváth, S. Beszédes, Sz. Kertész, E. Gyimes, C. Hodúr, Comparison of the effects of ozone, UV and combined ozone/UV treatment on the colour and microbial counts of wheat flour. Ozone Science \& Engineering Journal, 30. 6. (2008) 419-417. 